\title{
Variation in spike initiation in some Piper longum germplasms of North East India
}

\section{Amrita Khound}

Krishi Vigyan Kendra (AAU), Baksa (Assam), India

D. Sharmah*

Krishi Vigyan Kendra (ICAR), South Tripura (Tripura), India

P.C Barua

Department of Horticulture, Assam Agricultural University, Jorhat-785013 (Assam), India

*Corresponding author. E-mail: dasharmah@gmail.com

\begin{abstract}
The risk of adverse reactions in herbal remedies is less and has become popular to be used traditionally for treating various diseases. The species associated with genus Piper are important medicinal plants used for preparation of herbal medicines. The present investigation was carried out in the Experimental farm, Department of Horticulture, Assam Agricultural University, Jorhat-13 during 2013-14 and 2014-15 to investigate the flowering variation of some Piper longum germplasms of North East India. A total of 16 Piper longum germplasms including 'Viswam' as check variety were evaluated and experimental data revealed significant difference in spike initiation time among the germplasms with shortest spike initiation period (245.30 days) that recorded in germplasm PLJ-19 while the check var. recorded 287.40 days. Significant and shortest period for spike initiation to maturity was recorded in germplasm PLJ-19 (61.04days) followed by PLJ-01 (61.00days), PLJ-11 (61.38days) and check var. (70.03days). The number of flowering spike per plant ranges in between 58.53-113.73. The highest number of flowering spike per plant 113.73 was observed in germplasm PLJ-19 followed by PLJ-01 (109.40), PLJ11 (104.11), PLJ-16 (100.33) and were found to be superior over check var. (92.07). The present findings has a significant contribution in determination and identification of germplasm having shorter spike formation period with higher number of flowering spike as the variation in piperine content depends on both the characters also.
\end{abstract}

Keywords: North East, Medicinal Plant, Piper longum, Spike formation, Variation

\section{INTRODUCTION}

Medicinal plants have shown great potential for the development of the new drug for various human diseases. Piper longum L. (Pipali) is a medicinal shrub with large woody root and numerous creeping, jointed stem, thickened at the node. It belongs to the family Piperaceae and dioecious in nature. Long pepper is typically found in tropical humid climate and prefers shade moist conditions, well drained sandy soil of $\mathrm{P}^{\mathrm{H}} 5.5$ to 8.5 with rich humus. The areas with good rainfall and high relative humidity are necessary for successful growth (Khound and Barua, 2016). It is a shade loving plant but, for better fruiting, $50 \%$ shade is best (Sumy et al., 2000). The plant bears unisexual flowers in solitary, erect spikes during or just after the rainy season. The male spikes are larger, slender and are 2.5 to $7.5 \mathrm{~cm}$ long while the female spikes are 1.25 to about $2 \mathrm{~cm}$ long. They produce two types of branches viz. vegetative branches (Orthotropic) that creep and spread and fruiting branches (Plagiotropic) that are erect
(Kapoor, 2001).

$P$. longum grows all over India, in evergreen forests of Assam, Khasi and Mikir hills, lower hills of West Bengal. In different agro-climatic regions of the country a number of geographical races exist. The main sources of supply being Assam and West Bengal and small quantities are being collected from Kerala (Ravindra and Balachandran, 2005) . Indian long pepper is also known as Pipoli (Assamese), Pipar, Pipal (Hindi), Hippali, Thippali balli (Kannada), Tippali, Pippali (Malayalam), Pimpli (Marathi), Pippli, Tippili (Tamil), Pippallu, Pippali (Telegu), Pippali, Kana, Ushana (Sanskrit) (Sumy et al., 2000).

$P$. longum is an important properties for drug capable of improving intellect and memory power and also to regain health by dispelling diseases. It has been found to possess antioxidant activity which neutralizes harmful effects of excessive free radicals produced in the body. It posses several medicinal properties as well as pharmacological action such as to treat chronic bronchitis, asthma, constipation, gonorrhea, paralysis of the tongue, 
diarrhea, cholera, chronic malaria, viral hepatitis, respiratory infections, stomachache, bronchitis, diseases of the spleen, cough, and tumors. (Kumer et al., 2011) and it is known to have insecticidal activity against mosquitoes and flies (Sharmah et al.,2018). Considering the importance of this medicinal plant, the present investigation was carried out with the objective to determine the prominent germplasm in relation to variation in spike formation and number of flowering spikes which are the important trait in increasing yield in $P$. longum (Joseph, 2008).

\section{MATERIALS AND METHODS}

A total of 16 germplasms (germplasm) of $P$. longumfrom different states of North East (Table 1) were collected including the only released variety "Viswam", as check, collected from Kerala Agricultural University, Trichur, Kerala. The experimental field was laid in Randomized Block design with three replications in a net area of $288 \mathrm{sqm}$ with individual plot size of $2 \mathrm{mX} 3 \mathrm{~m}$. All post planting recommended operations was carried out to raise the crop.

Data recording: A total of five plants per plot were selected randomly and tagged for data recording. To count the number of flowering spikes, five selected plants of each plot were considered and total number of flowering spike per plant was calculated during the whole flowering season and the mean was calculated accordingly Manual, 2004 and Kanimozhi, 2010). A total of five flowers per plant were marked and days required from planting to initiation of spike was calculated in first crop and in second crop, the same was calculated from days taken after harvesting of first crop. A total of randomly selected five spikes per plant were marked and number of days taken from initiation to maturity was calculated (Manual, 2004 and Kanimozhi, 2010).

Statistical analysis: The experiment was conducted in a Randomized Block Design (RBD) with three replications and collected data were analyzed using PASW statistics 18 computer based programme.

\section{RESULTS AND DISCUSSION}

The shortest initiation period (245.30days) was recorded in germplasm PLJ-19 followed by germplasm PLJ-01 which recorded 253.07 days while the check var. recorded (287.40 days) for the first crop while in the second crop the shortest initiation period was recorded in PLJ-19 (197.40 days) followed by PLJ-01 which recorded 203.10 days and the check recorded 239.38 days (Table 2). Similar results were reported by Rajamani (2001) that in check var. "Viswam" days required from planting to initiation of spike ranged in between 240 days to 270 days which is not in accordance with Maheswari and Suma (2012) that planting to emergence period ranged in between 77 to 146 days. This may be due to the vigorous growth of the plants at conducive soil moisture led to the production of endogenous metabolites that enable early spike initiation. The initiation of spike was observed during late winter may be due to some genetic or hormonal changes of this collected germplasm prevailing in this region. The shortest period of maturity 61.04 days was recorded in germplasm PLJ-19 followed by germplasm PLJ-01 (61.00days), PLJ-11 (61.38days) and check var. recorded (70.03days) (Table 2). Maheswari and Suma (2012) reported that initiation to maturity period of spike ranges in between 60 to 80 days in Piper longum that confirmed the present findings. The highest number of flowering spike per plant 113.73 was recorded in germplasm PLJ-19 followed by germplasm PLJ-01 (109.40), PLJ-11 (104.11), PLJ-16 (100.33) which were found to be superior over the check var. (92.07) (Table 2). The increase in number of flowering spikes per plant might be due to higher availability of major nutrients that leads to higher uptake by plants. But all the flowering spikes do not turn into fruiting

Table 1. Particulars of selected Piper longum germplasms collected from different places.

\begin{tabular}{lll}
\hline Sl. No. & Piper longum germplasms & Place of collection \\
\hline 1 & $\mathrm{G}_{1}=$ PLJ-18 & Banderdewa, Arunachal Pradesh \\
2 & $\mathrm{G}_{2}=$ PLJ-19 & Bokakhat, Assam \\
3 & $\mathrm{G}_{3}=$ PLJ-17 & East kameng, Arunachal Pradesh \\
4 & $\mathrm{G}_{4}=$ PLJ-09 & Umrangso, Meghalaya \\
5 & $\mathrm{G}_{5}=$ PLJ-01 & Khetri, Assam \\
6 & $\mathrm{G}_{6}=$ PLJ-03 & Namgui, Arunachal Pradesh \\
7 & $\mathrm{G}_{7}=$ PLJ-22 & Kadamtal, Assam \\
8 & $\mathrm{G}_{8}=$ PLJ-20 & Jagirod, Assam \\
9 & $\mathrm{G}_{9}=$ PLJ-10 & Kahikuchi, Assam \\
10 & $\mathrm{G}_{10}=$ PLJ-11 & Sarupathar, Assam \\
11 & $\mathrm{G}_{11}=$ PLJ-29 & Barpeta, Assam \\
12 & $\mathrm{G}_{12}=$ PLJ-28 & Mirza, Assam \\
13 & $\mathrm{G}_{13}=$ PLJ-16 & Dharmanagar, Tripura \\
14 & $\mathrm{G}_{14}=$ PLJ-30 & Boxirhat, Assam \\
15 & $\mathrm{G}_{15}=$ PLJ-32 & Siang, Arunachal Pradesh \\
16 & $\mathrm{G}_{16}=$ Viswam & Check var. from Kerela \\
\hline
\end{tabular}


Khound, A. et al. / J. Appl. \& Nat. Sci. 11(3): 684 - 686 (2019)

Table 2. Variation in initiation of spike, spike initiation to maturity and number of flowering spikes.

\begin{tabular}{|c|c|c|c|c|c|c|c|c|}
\hline \multirow[t]{2}{*}{ Germplasm } & \multirow{2}{*}{$\begin{array}{l}\text { Days from } \\
\text { planting to } 1^{\text {st }} \\
\text { crop spike } \\
\text { initiation }\end{array}$} & \multirow{2}{*}{$\begin{array}{l}\text { Days after } 1^{\text {st }} \\
\text { crop harvest to } \\
2^{\text {nd }} \text { crop spike } \\
\text { initiation }\end{array}$} & \multicolumn{3}{|c|}{ Spike initiation to ma- } & \multicolumn{2}{|c|}{$\begin{array}{l}\text { Number of } \\
\text { spike/plant }\end{array}$} & flowering \\
\hline & & & $\begin{array}{l}1^{\text {st }} \\
\text { crop }\end{array}$ & $\begin{array}{l}2^{\text {nd }} \\
\text { crop }\end{array}$ & $\begin{array}{l}\text { Pooled } \\
\text { mean }\end{array}$ & $\begin{array}{l}1^{\text {st }} \\
\text { crop }\end{array}$ & $\begin{array}{l}2^{\text {nd }} \\
\text { crop }\end{array}$ & $\begin{array}{l}\text { Pooled } \\
\text { mean }\end{array}$ \\
\hline PLJ-18 & 276.07 & 226.07 & 66.73 & 69.13 & 67.93 & 94.65 & 95.69 & 95.17 \\
\hline PLJ-19 & 245.30 & 197.40 & 59.80 & 62.20 & 61.00 & 113.21 & 114.25 & 113.73 \\
\hline PLJ-17 & 292.17 & 242.07 & 69.88 & 72.28 & 71.08 & 89.75 & 90.79 & 90.27 \\
\hline PLJ-09 & 323.12 & 271.13 & 71.84 & 74.24 & 73.04 & 80.61 & 81.65 & 81.13 \\
\hline PLJ-01 & 253.07 & 203.10 & 59.84 & 62.24 & 61.04 & 108.88 & 109.92 & 109.40 \\
\hline PLJ-03 & 314.09 & 264.13 & 70.87 & 73.27 & 72.07 & 83.74 & 84.78 & 84.26 \\
\hline PLJ-22 & 308.73 & 258.73 & 70.80 & 73.20 & 72.00 & 86.08 & 87.12 & 86.60 \\
\hline PLJ-20 & 272.15 & 222.17 & 65.83 & 68.23 & 67.03 & 97.78 & 98.82 & 98.30 \\
\hline PLJ-10 & 279.13 & 229.13 & 67.84 & 70.24 & 69.04 & 91.68 & 92.72 & 92.20 \\
\hline PLJ-11 & 258.08 & 208.10 & 60.18 & 62.58 & 61.38 & 103.59 & 104.63 & 104.11 \\
\hline PLJ-29 & 337.29 & 289.30 & 72.73 & 75.13 & 73.93 & 76.55 & 77.59 & 77.07 \\
\hline PLJ-28 & 341.20 & 291.19 & 72.81 & 75.21 & 74.01 & 58.01 & 59.05 & 58.53 \\
\hline PLJ-16 & 264.22 & 214.23 & 64.87 & 67.27 & 66.07 & 99.81 & 100.85 & 100.33 \\
\hline PLJ-30 & 335.22 & 285.24 & 71.87 & 74.27 & 73.07 & 78.48 & 79.52 & 79.00 \\
\hline PLJ-32 & 302.05 & 252.07 & 70.53 & 72.93 & 71.73 & 86.39 & 87.43 & 86.91 \\
\hline Check var. & 287.39 & 239.38 & 68.83 & 71.23 & 70.03 & 91.55 & 92.59 & 92.07 \\
\hline S. Ed $( \pm)$ & 1.00 & 5.53 & & & 0.89 & & & 2.31 \\
\hline CD $(5 \%)$ & 2.04 & 11.28 & & & 1.82 & & & 4.71 \\
\hline $\mathrm{SD}( \pm)$ & 1.29 & 7.14 & & & 1.15 & & & 2.98 \\
\hline LSD & 2.63 & 14.56 & & & 2.35 & & & 6.08 \\
\hline
\end{tabular}

Data are means of three replications

spike. This may be due to variation in the weather parameters like heavy rain fall and high relative humidity during spike initiation period of Pipper longum (Rajamani, 2001).

\section{Conclusion}

From the present investigation it can be concluded that the shortest spike initiation period, spike initiation to maturity and highest number of flowering of $P$. longum $\mathrm{g}$ of North East India were in germplasm PLJ-19 followed by PLJ-01, PLJ-11 and check var. The present findings has a significant contribution in determination and identification of germplasm having shorter spike formation period with higher number of flowering spike as the amount of piperine content depends on both the characters. Considering the medicinal importance of this plant, the present investigation will certainly be helpful to increase piperine production as same is dependent on spike formation period and number of flowering spike present in a germplasm.

\section{ACKNOWLEDGEMENTS}

The Authors are thankful to the Directorate of Medicinal and Aromatic Plants (ICAR), Anand, Gujarat for their help in the present Research Programme.

\section{REFERENCES}

1. Kanimozhi, K. (2010). Exploitation of bisexual variant in developing high yielding types of Piper longum $\mathrm{L}$. M.Sc. (Hort). Thesis, Kerala Agricultural University, Thrissur. pp. 43

2. Joseph, R. (2008). Evaluation of ecotypes of long pepper (Piper Longum L.). M Sc. (Hort.) thesis, Kerala Agricultural University, Thrissur, pp. 77.

3. Kapoor, L. D. (2001). Handbook of Ayurvedic Medicinal Plants: Herbal Reference Library, CEC Press, PP 416.

4. Khound, A. and Barua, P. C. (2016). Influence of weather parameter on flowering and fruiting spike of medicinal plant Piper longum L. Advance Research Journal in Crop Improvement. 7(2): 8-12.

5. Kumar, S., Kamboj, J., Suman, Sharma, S. (2011). Overview for Various Aspects of the Health Benefits of Piper Longum Linn. Fruit. Journal of Acupunct Meridian Studies, 4 (2):134-140.

6. Maheswari, R. S. N. and Suma, B. (2012). Evaluation of long pepper (Piper longum $\mathrm{L}$ ) genotypes for growth flowering and yield. M.Sc. Thesis, KAU.

7. Rajamani, K. (2001). Performance of Tippli (Piper longum) in shevroy hills.In: Paper presented at the National Seminar on Conservation and Utilization of Medicinal and Aromatic Plants, held at Bhubaneswar during 4-6 December.

8. Manoj, P., Soniya, E. V., Banerjee, N.S. and Ravichandran, P. (2004). Recent studies on well known spice Piper longum. Linn. Natural Product Radiance. 3(4): July-Aug.

9. Manual, J. (2004). Comparative evaluation of selected types of Piper longum L. in coconut plantation. M.Sc. (Hort). Thesis, Kerala Agricultural University, Thrissur. Pp. 109.

10.Ravindran and Balachandran (2005). Thippali - the Indian long pipper - the most widely used medicinal plant of India. Spice India. 18 (11): 32-42.

11.Sharmah, D., Sharmah, A. K, and Rahman, S. (2018). Phytochemicals derived from Piper longum in insect and mite pests management: A review. Journal of Applied and Natural Science. 10(2): $553-556$.

12.Sumy, O., Ved, D. K. and Krishnan, R. (2000). Tropical Indian Medicinal Plants, Propagation methods, pp. 268-269. 